\title{
The Impact of Firm Characteristics in Access of Financing by Small and Medium-sized Enterprises in Tanzania
}

\author{
Alex Reuben Kira ${ }^{1} \&$ Zhongzhi He${ }^{1}$ \\ ${ }^{1}$ Shanghai University of Finance and Economics, School of Finance, Shanghai, China \\ Correspondence: Alex Reuben Kira, Shanghai University of Finance and Economics, School of Finance, 777 \\ Guoding Rd., Shanghai, China. Tel: 86-137-7436-1320. E-mail: alexkira10@gmail.com
}

Received: August 14, 2012 Accepted: October 30, 2012 Online Published: November 28, 2012

doi:10.5539/ijbm.v7n24p108

URL: http://dx.doi.org/10.5539/ijbm.v7n24p108

\begin{abstract}
The contribution of Small and Medium-sized Enterprise (SME) sector in economic development, job creation and income generation has been recognized worldwide. However, these contributions are not effectively harnessed in Tanzania. The main challenge limiting the sector to contribute fully is a shortage of finance. This study examines the impact of firm characteristics in access to debt financing by Tanzanian SMEs. The equation specified access to finance as dependent variable while firm characteristics as independent variable. Data collection was conducted through self-administered questionnaire in a survey of 163 Tanzanian firms. The statistical analysis of data involved Pearson correlation and logistic regression to establish the association between dependent and independent variables. The results indicate that firm's location, industry, size, business information, age, incorporation and collateral influence access to debt finance. The study recommends that Tanzanian SME operators should maintain attractive firm attributes to stimulate lenders to extend debt financing to their investments.
\end{abstract}

Keywords: firm characteristics, debt financing, small and medium-sized enterprises (SMEs)

\section{Introduction}

The Small and Medium-sized Enterprise (SME) sector performs a significant roles worldwide (Abor et al., 2008). SMEs have a potential contribution socially and economically by contributing noticeably in job creation, revenue creation, innovations, as well as a catalyst for urban and rural area's growth (Hallberg, 2000; OECD, 2004; Williams, 2006; Fatoki \& Asah, 2011). Most of the industrialized countries, over $98 \%$ of all manufacturing sector firms originate from the SMEs sector and they are main employment providers (Sanusi, 2003). The SME sector employs more than $22 \%$ of the productive labor force in the developing countries (Kayanula et al., 2000).

In Tanzania, the government has been attracted by SMEs to solve unemployment problem which recently is spreading across the country. More than 700,000 job seekers enter the Tanzanian labor market annually but only 40,000 new jobs are created annually within formal sector, therefore those who unable to find jobs in the formal sector end up in the informal sector whereby SMEs dominate (Olomi, 2005). Despite of SMEs contributions in the county's job creation, their continuing growth and strengthens has been compromised by the persistent limitations on their access to financing from formal-sector. The finance gap exists in the Tanzanian SME sector deteriorate SMEs' productivity, performance and contributions to the country's economy.

Tanzania government by recognizing the importance of SMEs in economic development has set up various programs (Note 1) aimed at developing the SME sector. The National Strategy for Growth and Poverty Reduction (NSGPR I \& II), famous known as MKUKUTA I \& II in Swahili, as a medium plan towards the eradication of poverty in the country by the year 2025 . The policy categorizes agricultural sector and informal business sectors as the main segments in which majority of disadvantaged people generates their income. The policy tempts to speed up growth in the economic activities in which the poor societies are dominant and those sectors which are left behind economically in Tanzania. In tackling the issue, the Property and Business Formalization Program "famous as MKURABITA in Swahili" was established to initiate and facilitate formalization of informal property and business entities in order to enhance their access to services enjoyed in the formal sector, and thus speed up their growth, ability to compete and survive within Tanzanian business environment. Practically, the Formalization Program seeks to establish an integrated system of property rights and business rules as a basis of transition of the urban, peri-urban and rural areas into a market that enables 
Tanzanians to have equal opportunities in using their assets to acquire credit services from lenders. Consequently, the program intends to steadily transform informal sector to an acceptable national limit to which the informal sector can be able to enjoy the benefits that are enjoyed by formal sector including easy access to credit facilities. Studies of the informal sector in Tanzania indicate that more than $90 \%$ of properties and business activities in the country operate in the sector. By implication, policies and strategies targeting economic growth and poverty reduction in Tanzania should fundamentally deal with activities in the informal sector (Note 2). However, these strategies and programs still unattainable, SME sector still vulnerable and very few manage to survive due to shortage of finance.

Pretorius and Shaw (2004) observed that accessibility to external finance is essential to solve shortage of SMEs cash flows. Financing is required for SMEs' to set up and enlarge their business operations, new product development, research and development, human resource development and acquirement of up-to-date production equipments and technology. Most of SMEs rely on internal finance (Note 3) since they can't afford external finance easily only prioritized source become internal finance but still internal finance is inadequate for SMEs' development and profitability. Most SMEs failures to access debt financing result into an inadequate capital structure.

Demirquc-Kunt et al. (2006) pointed out that the main source of external financing for SMEs is equity and debt. Shane (2008) observed that external equity from stock exchange (capital markets) usually never exists for SMEs. Majed et al., (2010) and Sorooshian et al., (2010) evidenced that firm characteristics (Note 4) have an impact on capital structure and performance of SMEs. Firm characteristics include attributes such as firm's location, firm industry, firm size, firm age, firm's legal status and the availability of collateral and business information.

The initial capital and expansion capital fund for Tanzanian SMEs has been a perpetual problem in even though the government still intending to empower the sector. Lending financial institutions have the capacity to pull their financial resources together to meet SMEs' credit needs but still they are unwilling to take part. Finance gap still exists between the supply capabilities of financing sources and the demanding needs for capital to SMEs. This study intends to create a bridge to impact accessibility of finance to Tanzanian SMEs.

\section{Objective of the Study}

The SME sector is an engine of economic growth of many economies in developing and developed countries as it plays a major role in job creation, competition, economic enthusiasm, and innovation. The sector stimulates the entrepreneurial fortitude and the dissemination of expertise. The main recognized achievement aspect for any SMEs is to gain adequate access to external sources of financing (Le, Venkatesh \& Nguyen, 2006). The objective of this study is to examine empirically the impact firm characteristics on access to finance by Tanzanian SMEs.

\section{Literature Review}

\subsection{Theoretical Framework}

The capital structure is described as the mix of debt and equity that a firm uses to finance its operations (Gitman, 2003; Brealey el at., 2008). The original hypothesis of capital structure originated from the Modigliani-Miller theorem (MM theory), the study argued that the value of the firm is irrelevant in financing decisions in a perfect market (Modigliani and Miller, 1958, 1963). The theory lacks applicability in the real world since the firm's value is relevant in financing decisions because of agency costs, bankruptcy costs, information asymmetry and tax components that impact firm's capital structure. The benefit to employ debt in a firm's capital structure exists as the interest on debt is tax-deductible, thus creating tax savings for the borrower (Modigliani \& Miller, 1963). Therefore, it is possible to reduce firm's costs of capital and maximize shareholders' wealth by employing debt. Tax saving makes debt finance cheaper than equity finance whenever employed in a firm's capital structure.

The combination of inexpensive debt with relatively expensive capital equity decreases a firm's cost of capital, which is the hurdle rate for investment acceptance or rejection decisions. For a project to be pursued must be viable to generate enough cash flows to cover the initial cost of that investment. MM theory stipulated that a firm should have $100 \%$ debt in its capital structure in order for a firm to enjoy the tax shield benefit (Miller \& Modigliani, 1963). Scott (1972) and Kraus and Litzenberger (1973) point out that theoretically 100\% tax shield does not exist because of the existence of financial distress costs (Note 5). The utilization of debt financing by a firm has a cost attached to a firm thereby to settle legal obligation including interest and principal. Failure to meet these legal obligations leads a firm to encounter liquidation and suffer the related settlement expenses.

Jensen and Mecling (1976) pioneered the concept of agency theory which explains the conflicts arise between the shareholders, managers and lenders collectively known as principal - agent problems. The conflict between stockholders and management arise when managers are not performing to attain the shareholders value 
maximization goal, literally shareholders incur costs to monitor managers and influence their action in which managers have to make viable decisions for the prosperity of the firm. In contrast, lenders are united with the shareholders in requesting firm's performance, but when firm face difficulties this unity of the purpose can collapse. The common goal of the union between lenders and shareholders is to take several necessary measures to rescue the firm. These conflicts will never exist if all stakeholders have the same information which is rarely to exist in finance. The presence of information asymmetries could lead managers, shareholders and lenders have different information about the value of a firm and it might take several years before all information is revealed to impact their decisions.

Stiglitz and Weiss (1981) stipulated that presence of agency problems such as asymmetric information and moral hazards can impact the access to finance and thereby capital structure of SMEs. The pecking order theory states that the presence of asymmetries of information among the stakeholders; most firms utilize in optimal internal sources available to finance their investments before opting to use debt and equity (Donaldson, 1961; Myers \& Majluf, 1984; Myers, 1984). SMEs face challenges in making decision on financing choices because of adverse selection problem which hinder their access to credit and it's expensive to solve the problem. SMEs' costs to finance their investment opportunities by issuing stock (stock market) are higher than debt financing. SMEs operators may decide to finance their investment by using either internal or external sources; when external source is priority the least risk should be selected.

Traditional tradeoff theories stipulate that firm's should decide optimal capital structure option by evaluating the tax saving available in debt; bankruptcy and agency costs of debt and equity basing on available information to maximize firm's value. The firm that maintains optimal debt in their capital structure minimizes the cost of capital therefore tends to maximize firm's value. Despite of financial distress problem exists when firm imply debt financing in their capital structure; SMEs imply debt as the only choice available because of insufficiency of internal sources and unavailability of equity finance (Frelinghaus et al., 2005).

\subsection{SMEs Perspectives in Debt Financing}

Obstacles exist on access of external financing for SMEs led the sector to experience investment fund hence impact sector's growth (Da Silva et al., 2007). Financing from internal or external source are required to stimulate firm's profitability which is the accelerator of the any business expansion and stability (Olutunla et al., 2008). Myers (1984) in pecking order theory states that during financing decision firms should prioritize internal sources of financing to external sources of financing in reference to availability of the source and cost involved. The internal sources of financing option are not preferred choice to be selected in financing profitable and viable projects by most firms because it is insufficient. The external financing is the only source to rescue the SME sector in Tanzania. The borrowed fund can be invested in profitable projects to generate additional assets that can be used as collateral in the future when firm is in need of external debt financing.

Refer figure 1 which represents diagrammatically how the accessibility to finance by SMEs can impact their performance.

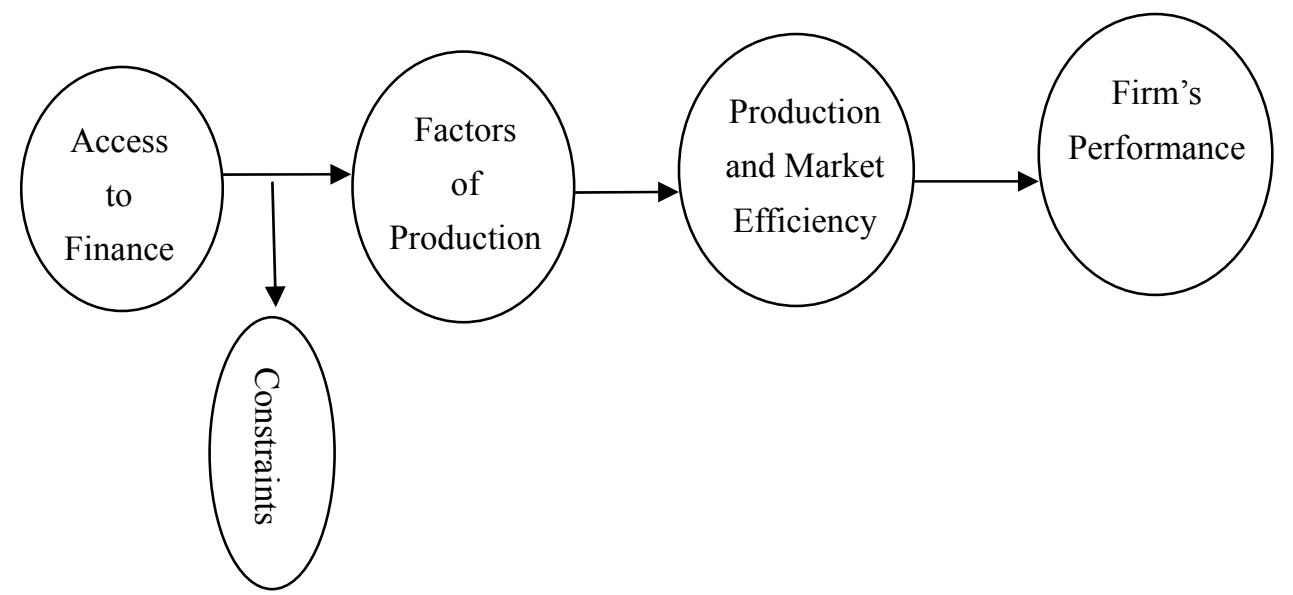

Figure 1. Diagrammatic model representation on how access to finance impact firm's performance

Thus, accessibility for finance (Note 6) to SMEs is predictable to positively influence the ownership and control of production factors i.e. land, labor and capital; subject to the constraints (Note 7) of asymmetric information 
and high cost of capital. For example, wages or salary, the cost to hire labor, is inversely related to the profitability and growth of the firm. Increase in wages or salary tend to force the producers incur higher production cost and otherwise hold. Ceteris paribus (Note 8), development of factors of production in terms of quality and quantity (i.e. application of new technology and machinery; well trained and qualified personnel) available to SMEs increase productivity and through efficient and resourceful market strategies (Note 9) enhance SME's performance and growth. Access to finance enables the SMEs to acquire productive assets that can be used to increase productivity simultaneously reducing the unit cost of production resulting to economies of scale. Decrease in unit cost of production tends to generate an increase in profit. Olutunla and Obamuyi (2008) point out that the improved firm's performance ensures higher earnings, increment in sales volume, creation of employment and wealth maximization. However, firm performances can be unattainable if SMEs fail to access debt financing to support their investment opportunities.

\subsection{Empirical Review: Firm Characteristics}

This part presents the empirical review of the firm characteristics to be used in this study. It introduces the variable, frameworks arising from the literature and discusses how it impacts debt financing by SMEs. It constructs relevant hypotheses to be tested in the study and other immediate literature of relevance to the study.

\subsubsection{Location of the Firm}

Berger and Udell (2002) find out that the geographic closeness between lenders and customers has an association with a firm to access to credit. The lenders who are geographically proximity to their customers are capable to utilize soft available qualitative information to establish the credibility of their customers for credit quality. Gilbert (2008) spotted that the location of the firm has a noticeable relationship with access to the marketplace, supplies and to other resources such as capital, labor, and land. Consequently, firms sited in urban locations may have a higher possibility of success than firms located in rural locations with access to credit, market and other resources. Fatoki and Asah (2011) find out that SMEs located in urban are successful in access to debt financing compared those located in rural areas. Physical closeness between lenders and borrowers produce an improved form of environmental scrutinize that aid SMEs to access credit from lenders. Consequently, there is a positive relationship between firm's location and access to debt financing by SMEs.

\subsubsection{Industry of the Firm}

The industry in which a firm operates does not influence the firm's capital structure directly but might do so indirectly through the composition and nature of the firm's assets (Hall et al., 2000). The association that exists between industrial classification and employment of debt in the capital structure originated from a theory which stated that industry classification is a substitute for business risk (Barbosa \& Moraes, 2004). The concept lay in this theory indicate the firms operating in the same business sector, the environment and economic features tend to suffer the same impact face the sector which might influence earnings and growth. Hall, Hutchinson and Michaelas (2000) advocated that even though particular firm features are sensitive to structural features of industry still financial strategy variables posse very important influence over industrial specific effects on the firm's operations. Abor (2007) evidenced that SMEs operate in the agricultural industry has strongest capital structure and asset structure whereby wholesale and retail industry demonstrated the weakest asset structure as well as debt ratio. Consequently, it is hypothetically exists a positive impact between the firm's industry and access to debt financing by SMEs.

\subsubsection{Firm Size}

The firm's size has a crucial weight on the debt proportion in the capital structure of the firm since real assets tend to influence the accessibility to long debt whenever required (Burkart \& Ellingsen, 2004). Large firms tend to be well diversified in their operations which influence their stability; thereby size can be substituted for insolvency (Honhyan, 2009). Cassar (2004) stipulated that small firms find more expensive in solving problems associated information asymmetry with lenders. Most of firms in Tanzania operate in SME sector featured with difficulties in start-up and growth barriers associated with a shortage of finance. Fatoki and Asah (2011) find out that firm size impacts SMEs access to debt finance from commercial banks whereby small enterprises are less favored to large firms. Consequently, it's hypothetical existence of a positive association between the firm size and SMEs access to debt financing.

\subsubsection{Firm's Business Information}

The objective of financial information presented by firms to their users is to inform them on different status of the firm's operations. Financial information issued by a firm state firm's performance, financial position at a particular point and changes in financial position in the firm's operations (Note 10). The firm's business 
information is useful by stakeholders in making different economic and social decisions. The users of this information include employees, lenders, government and their agencies, employees, suppliers and other creditors, customers and the general public. This study evaluates why lenders (banks and other lending agencies) are interested with firm's business information. Kitindi et al., (2007) point out that lenders use firm's business information to assess current and future performance of the firm. Lenders are interested to know the status of their loan interest and principal by evaluating the firm's capital structure. Furthermore, lenders use the business information to decide borrower's credibility whether to issue or extend a loan or not. Absence of sufficient information leads to information asymmetry and may jeopardize access to credit finance (Sarapaivanich \& Kotey, 2006). Consequently, it is the hypothetical existence of a positive association between business information and access to debt financing SMEs.

\subsubsection{Age of the Firm}

Firms at the early stage of operation used to experience difficulties in access to debt finance because of informational disparities. The firm starts to operate and grows with business performances on a trade which create a reputation on credit history. Credit reputation reduces the moral hazard dilemma hence create a path to access debt finance. The longevity of the firm stays in operation, the more persistence to unpleasant economic circumstances (Chandler, 2009). The study conducted by Klapper (2010) discovered that, the firms with less than 5 years (younger firms) in operation are less likely to rely on debt financing from lenders. Ngoc, Le and Nguyen (2009) supported the argument that younger firms face hardship and more costs in accessing external financing from lenders because information asymmetry. Consequently, it is hypothetical existence of a positive relationship between firm's age and access to debt finance by SMEs.

\subsubsection{Legal Status of the Firm (Incorporation)}

Dietmar et al., (1998) point out that firm with limited liability (incorporated) possess development attributes than firm with unlimited liability. There are numerous aspects that clarify the relationship that exist between incorporation and access of debt financing: one, the separation of owner's affairs and business affairs increase the commitment of managers to the firm goals. Two, Publication of their financial statements as one of legal requirement makes corporation's openness for users to know the firm's status including their debt ratio and firm's assets. Cassar (2004) found out that lenders observe incorporation as a good indicator for firm's trustworthiness and commitment to operational laws. Abor (2008) stated that the form of business organization has an effect on equity - debt decisions on SMEs operations. The owners of limited firm have limitations to answer against losses generated by the corporation whereby the owners of unlimited forms of organization (sole proprietorship and partnership) are liable up to their personal assets to cover for business losses. Therefore, limited companies prefer to use the equity to finance their projects than debt financing while unlimited form of business organizations (sole proprietorship and partnership) the only option available to finance their projects is debt financing. The study conducted by Coleman and Cohn (2000) and Fatoki and Asah (2011) evidenced presence of a positive association between debt financing and legal formation of business organization. Consequently, we proposed the existence positive relationship between incorporation and access of debt financing by SMEs.

\subsubsection{Firm's Collaterals}

SME sector faces difficulties to access external finances for their investment projects because of lack of assets to be pledged as collateral. In that perspective SMEs fail to grow due to lack of collateral to pledge to access external sources of finance. Bougheas, Mizen, and Yalcin, (2005) pointed out that the requirement of collateral is a crucial aspect for SMEs to succeed in accessibility of external financing from lenders. Coco (2000) suggested that the collateral is the lender's protection incase default happened by a borrower, in that perspective collateral is the insurance that lender's contract will be honored and respected. Collateral solves the information asymmetry problems in the evaluation of investment project, the worthiness of the project and risk that might be involved by a borrower as well as the cost related to supervision of borrower's characters. Barbosa and Moraes, (2004) and Fatoki and Asah, (2011) suggested that operators of SMEs have to own more tangible assets that can create higher value on their firm to accelerate borrowing security. Because, the higher the value of assets the lower the interest rates of the debt to be secured by those assets. Consequently, it is hypothetical existence of a strong positive relationship between collateral and access of debt financing by SMEs.

\section{Research Methodology}

The empirical study focused on Coastal zone (Dar es Salaam), Northern zone (Arusha), Zanzibar (Unguja) and Southern and Highlanders zone (Mbeya) of United Republic of Tanzania. The study captured both qualitative and quantitative data. Data collection was conducted through a survey questionnaire comprising open and closed 
questions. The questions were comprehensible and constructed easily for respondents to understand and reply the questions. The survey was conducted by a small team of 2 researchers and 4 research assistants who distributed questionnaires and conducted interviews with owners and managers from surveys SMEs. This study concentrated on SMEs which are recognized by the Ministry of Industry, Trade and Marketing; Tanzania Chamber of Commerce and Small Industries Development Organization (SIDO). The population of SME was 300. To establish the sample size of this study we opted for Raosoft sample size calculator (Note 11) to calculate the sample size. The results provided by Raosoft was a minimum recommended sample size of 169 SMEs to be involved in our study but 200 were distributed because of data collection limitation such as non response. In data analysis we used the Statistical Package for Social Sciences (SPSS). The questionnaire was tested as our research instrument through a pilot study covering 20 SMEs operators. The purpose of the pilot study was not only to identify the common problems within the designed questionnaire but also to incorporate the respondent's comments that enhanced the quality of the questionnaire that met the purpose of study. Statistical analysis includes Pearson correlation, logistic regression and descriptive statistics. Pearson correlation was used to analyze the relationships exist between the variables and access to debt financing as well as establish if the multicollinearity between variables exist. Multiple Linear Regressions were used to measure the relationships between the independent and dependent variables. Validity and reliability were guaranteed by using a statistician and a panel of experts to weigh up the research instrument for theoretical clarity, pre-testing the research instrument in a pilot study and in depth reviewing the literature for theoretical constructs and empirical conclusions relating to this study.

\section{Results and Discussions}

Two hundred questionnaires were distributed and one hundred and sixty three $(81.5 \%)$ was returned. The questionnaires were structured to catch up with respondents who were operating in SME sectors and were potentially in need of debt finance. The study assesses how the firm's characteristics impact firm's credit accessibility from lenders in Tanzania.

\subsection{Correlation Analysis of Variables}

Correlation analysis was conducted to establish the degree of correlation on the variables intended for this study. The variables are: Location of the firm; Industry of the firm; Business firm's information; Size of a firm; Age of a firm; Collateral; and Incorporation. To establish the relationship of these variables; we first run a correlation analysis among the variables to find out the association exist between the independent variables and the dependent variable as well to establish whether the multicollinearity problem exists among the independent variables.

Table 1. Correlation of the variables

\begin{tabular}{|c|c|c|c|c|c|c|c|c|c|}
\hline \# & Variables & 1 & 2 & 3 & 4 & 5 & 6 & 7 & 8 \\
\hline 1. & Loan Access (Lappl) & 1 & $0.757^{* *}$ & 0.031 & $0.172^{*}$ & $0.163^{*}$ & $0.172^{*}$ & $0.632^{* *}$ & $0.201^{*}$ \\
\hline 2. & Location (Loc) & $0.757^{* *}$ & 1 & 0.039 & $0.212^{* *}$ & 0.132 & 0.145 & $0.578^{* *}$ & 0.131 \\
\hline 3. & Industry (Ind) & 0.031 & 0.039 & 1 & 0.091 & 0.115 & 0.003 & 0.031 & -0.091 \\
\hline 4. & Size (Size) & $0.172^{*}$ & $0.212^{* *}$ & 0.091 & 1 & $0.267^{* *}$ & -0.075 & 0.131 & -0.067 \\
\hline 5. & Business Information (BInfo) & $0.163^{*}$ & 0.132 & 0.115 & $0.267^{* *}$ & 1 & 0.121 & 0.063 & -0.073 \\
\hline 6. & Age (Age) & $0.172^{*}$ & 0.145 & 0.003 & -0.075 & 0.121 & 1 & 0.127 & 0.092 \\
\hline 7. & Collateral (Collt) & $0.632^{* *}$ & $0.578^{* *}$ & 0.031 & 0.131 & 0.063 & 0.127 & 1 & 0.143 \\
\hline 8. & Incorporation (Inco) & $0.201^{*}$ & 0.131 & -0.091 & -0.067 & -0.073 & 0.092 & 0.143 & 1 \\
\hline
\end{tabular}

**. Correlation is significant at the 0.01 level (2-tailed).

*. Correlation is significant at the 0.05 level (2-tailed).

The results of Correlation analysis show that: Location $(r=0.236 ; p=0.00)$, Industry of the firm $(r=0.238 ; p=$ $01)$, Size of firm $(r=0.481 ; p=0.03)$, Business information $(r=0.481 ; p=0.04)$; Age of the firm $(r=0.251 ; p=$ $0.03)$; Collateral $(r=0.632, p=0.000)$ and Incorporation $(r=0.239 ; p=0.01)$. All results indicate variables are positively correlated with access to debt finance. Results indicate that accessibility of debt finance from external sources in Tanzania is positively impacted by the firm's location, industry, size, age, and incorporation, the 
availability of collateral and business information.

Furthermore, the correlation coefficients show that there is no high correlation among independent variables used in this analysis, and thus make us to understand that no multicollinearity problem exists among the variables. The study conducted Field (2005) hypothesize that multicollineality is likely to be a problem in a data set if the correlation coefficient between predictors is greater than $0.90(\mathrm{r}>0.90)$.

\subsection{Logistic Regression Analysis}

Several approaches can be used by a researcher to model metric or dichotomous variables; include probit, logistic regression and discriminant function analysis. Conversely, logistic regression is famous approach and mostly is used to analyze the relationship between dichotomous dependent variables or independent dichotomous variables because of its flexibility and strongly to violation of the normality assumption within a model (Agresti, 1996). Logistic regression also authorizes forecast of a dependent variable from a set of predictors that may be discrete, dichotomous, and continuous or a combination of any of these (Fabowale et al., 1995). Alternatively, while discriminant analysis can be used to model dichotomous dependent variables, the analysis is only used with continuous predictors (Fabowale et al., 1995). The nature of data involved in this study we opted to analyze our data by using logistic regression to establish the extent to which each of the variables play a part in firm's access to debt financing.

\subsection{Econometric Model}

Econometric model was used to hypothesize the influence of firm characteristics on access to debt financing by SMEs in Tanzania.

Table 2. Results of logistic regression

\begin{tabular}{|c|c|c|c|}
\hline Variable & Odd Ratio & Confidence interval (95\%) & P-value \\
\hline \multicolumn{4}{|l|}{ Location } \\
\hline Urban & 7.12 & $3.52-7.08$ & 0.010 \\
\hline Rural & 1.01 & $2.05-3.26$ & 0.453 \\
\hline \multicolumn{4}{|l|}{ Firm Industry } \\
\hline Primary & 1.43 & $0.68-2.79$ & 0.250 \\
\hline Secondary & 5.82 & $2.35-7.65$ & 0.038 \\
\hline Tertiary & 2.85 & $2.05-6.32$ & 0.210 \\
\hline Quaternary & 1.33 & $2.11-3.21$ & 0.450 \\
\hline \multicolumn{4}{|l|}{ Firm Size } \\
\hline Small & 2.68 & $2.75-3.92$ & 0.325 \\
\hline Medium & 5.35 & $3.11-6.58$ & 0.043 \\
\hline Large & 6.33 & $2.03-7.65$ & 0.012 \\
\hline \multicolumn{4}{|l|}{ Business Information } \\
\hline Keep Business Information & 7.85 & $2.65 \quad-5.98$ & 0.005 \\
\hline Do not keep Business Info. & 2.85 & $2.13-3.78$ & 0.326 \\
\hline \multicolumn{4}{|l|}{ Firm Age } \\
\hline $1-4$ years & 1.12 & $0.35-1.42$ & 0.532 \\
\hline $5-9$ years & 4.58 & $2.42-6.32$ & 0.032 \\
\hline $10-14$ years & 5.26 & $3.25 \quad-6.92$ & 0.024 \\
\hline More than 15 years & 7.01 & $3.11-8.86$ & 0.042 \\
\hline \multicolumn{4}{|l|}{ Incorporation } \\
\hline Ltd company & 4.53 & $2.24-7.85$ & 0.043 \\
\hline Sole proprietorship or Partnership & 3.01 & $2.14-3.25$ & 0.321 \\
\hline others & 1.23 & $0.43-1.59$ & 0.354 \\
\hline \multicolumn{4}{|l|}{ Collateral } \\
\hline Required for loan approved & 8.75 & $3.05-8.12$ & 0.001 \\
\hline Not required for loan approval & 1.23 & $2.15-3.65$ & 0.392 \\
\hline
\end{tabular}




$$
\begin{gathered}
\text { Loans }_{j t}=\alpha_{1} \text { Loc }_{j t}+\alpha_{2} \text { Ind }_{j t}+\alpha_{3} \text { Binfo }_{j t}+\alpha_{4} \text { Size }_{j t}+\alpha_{5} \text { Age }_{j t}+\alpha_{6} \text { Collt }_{j t}+\alpha_{7} \text { Incop }_{j t}+\varepsilon_{j t} \\
\alpha_{1}>0 ; \alpha_{2}>0 ; \alpha_{3}>0 ; \alpha_{4}>0 ; \alpha_{5}>0 ; \alpha_{6}>0 ; \alpha_{7}>0
\end{gathered}
$$

Where: Loans $_{\mathrm{jt}}=$ Credit access by a firm $\mathrm{j}$ at time $\mathrm{t} ; \operatorname{Loc}_{\mathrm{jt}}=$ Location of a firm $\mathrm{j}$ at time $\mathrm{t} ; \operatorname{Ind}_{\mathrm{jt}}=$ Industry of a firm when firm $j$ at time $t$; Binfo $_{j t}=$ Business information kept by a firm $j$ at time $t ;$ Size $_{j t}=$ Size of a firm $j$ (measured by the number of employees) at time $t ; A_{j e}{ }_{j t}=A g e$ of a firm $j$ at time $t ;$ Collt $_{j \mathrm{t}}=$ Collateral firm possess when applying for a loan at time $t$; and $\operatorname{Incop}_{\mathrm{jt}}=$ Incorporation or Legal status of a firm during the loan application at time t. $\alpha_{1} \alpha_{2} \alpha_{3} \alpha_{4} \alpha_{5} \alpha_{6}$ and $\alpha_{7}$ are parameters to be estimated. $\varepsilon_{j \mathrm{jt}}$ is the error component that varies over both individual firms and time.

Theoretically, our expectations concerning the coefficients of the variables involved in this study: Location $\left(\operatorname{Loc}_{\mathrm{jt}}\right)$; Industry $\left(\mathrm{Ind}_{\mathrm{jt}}\right)$; Business information $\left(\right.$ Binfo $\left._{\mathrm{jt}}\right)$; Size $\left(\right.$ Size $\left._{\mathrm{jt}}\right)$; Age $\left(\mathrm{Age}_{\mathrm{jt}}\right)$; Collateral $\left(\mathrm{Collt}_{\mathrm{j} t}\right)$; and Incorporation $\left(\right.$ Incop $\left._{\mathrm{jt}}\right)$ of a firm is to carry positive signs. The data for the dependent and independent variables used in the regression analysis were collected from the primary data from field survey.

The coefficient of firm's location was positive and statistically significant and confirms our expectations of our hypothesis. The odd ratio for a firm situated in the urban location is 7.12 with a p-value 0.010 while for a firm located in rural areas has odd ratio of 1.01 with p-value 0.453 ; This implies that access to debt financing is positively related to firm's location; Firms located in urban areas have a higher possibility on access to loan or debt financing than firms located in the rural area.

The coefficient of industry of the firm was positive and statistically significant and confirms our hypothesis. The odd ratio for primary firm industry (Note 12) is 1.43 with a p-value 0.250 ; odd ratio for secondary industry (Note 13 ) is 5.82 with a p-value 0.038 ; odd ratio for tertiary industry (Note 14 ) is 2.85 with a p-value of 0.210 ; while odd ratio for quaternary industry (Note 15 ) is 1.33 with a p-value of 0.450 . This implies that access to debt financing is positively related to firm's industry whereby most of the sources of financing prefer lending more to the secondary sector while other sectors left unsupported by lenders.

The coefficient of size of business (measured by the number of employees) confirms to our hypothesis carrying a positive sign and is statistically significant. The odd ratio for small firms' is 2.68 with a p-value 0.325 ; odd ratio for medium firms' is 5.35 with a p-value 0.043 ; while the odd ratio for large firms' is 6.33 with a p-value of 0.012; results show that larger firms have higher access to debt financing than smaller and medium sized firms because of economies of scale. Larger firms find easier to borrow money from banks for expansion thereby enjoy the economies of scale. Large firms manage to purchase in large scale materials and factors of production such as capital, equipment and machinery as well as employing qualified workers who will ultimately increase productivity and profitability while SMEs are referred as risk borrowers by lenders.

Lenders (i.e. creditors, banks and other sources of finance) tend to utilize financial information issued by firms to evaluate and forecast the future performance of the firm. Information acquired from the firm's financial statements portrays the firm's forecasted financial capability and indicate whether their loan interest and principal could be settled when due. The odd ratio for firms' that maintain financial information is 7.85 with a p-value 0.005 while the odd ratio for the firms which do not maintain financial information is 2.85 with a p-value 0.326 . The result indicates that firms which maintain business information have higher possibility to access debt financing than those never maintain financial information. Therefore, our study confirms the existence of a positive relationship between the availability of business information and access of debt financing by SMEs.

The coefficient of the firm's age indicates a positive association between access to credit loan and age of the firm as per our hypothesis. The odd ratio for firms less than 5 years (younger firms) is 1.12 with a p-value of 0.532 ; the odd ratio for firms between 5-9 years is 4.58 with a p-value of 0.032 ; the odd ratio for firms between 10-14 years is 5.26 with a p-value 0.024 while the odd ratio for aged firms ( 15 years and above) is 7.01 with a p-value 0.042; The result indicates that older firms find easier to access debt financing than younger firms. Regarding the study results, Tanzanian business environment demonstrates a positive relationship between access of loan and age of business which is a burden to young firms whereby SMEs are dominant.

The results supported Coleman and Cohn (2000) findings on the existence of a positive association between the firm employing debt with incorporation and as per our hypothesis. The odd ratio for limited firms' is 4.53 with a p-value 0.043; the odd ratio for the sole proprietorship and partnership (Note 16) is 3.01 with a p-value 0.321 . This study finds out most of the firms operating as a sole proprietorship or partnership face difficulties in access the debt finance from lenders as because of high costs and lack of trust. Openness declared in the financial statements and limited liability make limited companies and corporation easy to access debt financing than unlimited liability forms of organization (partnership and sole proprietorship). 
The availability of collateral coefficient indicates a positive relationship with access to finance. Collateral is a decisive aspect for borrower to succeed in accessibility of debt financing from lenders. The odd ratio for firms' with collateral is 8.75 with a p-value 0.001 while the odd ratio for the firms which do not have collateral is 1.23 with a p-value 0.322 . The results indicate that lack of collateral by SMEs hinder their access to debt financing. Most of the firms rejected were those lack assets to be pledged as collateral. Therefore our results support Bougheas et al., (2005) that collateral requirement is a key characteristic for SMEs to succeed to access debt finance.

\section{Conclusion and Policy Implications}

The study has contributed to our knowledge on the series of factors associated with the firms' characteristics impacts on access to debt financing from different external sources of financing in Tanzania. The results demonstrate that there is interdependence and significant relationship between the firms' characteristics (location, industry, size, incorporation, age, size, availability of business information and collateral) and access of debt to financing by SMEs. The study recommends the following: One, that government should formulate policies that will make sources of financing (commercial banks, finance companies, micro finance institutions and other sources) to relax their restrictive regulations and operations which discourage borrowing and offer more credit facilities for firms especially SMEs. Two, government should support the SMEs sector by guaranteeing from financial institutions to SMEs. Third, government through central bank should either create strategies to stimulate commercial banks to increase their lending towards SMEs sector; or. Fourth, the government has to authorize special capital from Central Bank to Commercial Banks purposely to lend SMEs since commercial banks are the giant player in the lending industry. Fifth, the government should establish a bank to deal with debt financing for SMEs sector; Sixth, SMEs operators have to start saving and invests more on tangible assets to be pledged as collateral to acquire external finance.

\subsection{Limitation of This Study}

The study considers mainly internal factors and left behind other sensitive external factors which may also effect lending to SMEs. The study conducted by Barbosa and Moraes (2004) revealed that external factors have contributed impact on the access to credit by firms. Moreover, this study concentrated on the demand side of access to debt financing by Tanzanian SMEs while suppliers of debt finance (Lenders) were not involved, more contributions could be discovered to create a bridge between Tanzanian SMEs and lenders if all parties were involved. If another study could be conducted to assess the credit gaps to SMEs in the supplier side (lenders) could provide additional results to assist policy makers in solving financing deficit to Tanzanian SMEs. Finally; the data did not permit us to involve other the noticeable features i.e. political and socioeconomic variables which possibly might impact SMEs' access to debt financing because these variables are difficult to be captured quantitatively in our study.

\section{References}

Abor, J. (2007). Industry Classification and the Capital Structure of Ghanaian SMEs. Studies in Economics and Finance, 24(3), 207-219. http://dx.doi.org/10.1108/10867370710817392

Abor, J. (2008). Determinants of the Capital Structure of Ghanaian firms. Small Business Economics. Retrieved from http://www. ideas.repec.org/p/aer/rpaper/rp_176.html

Agresti, A. (1996). Introduction to categorical data analysis. John Wiley.

Barbosa, E. G., \& Moraes, C. C. (2004). Determinants of the firm's capital structure: The case of the very small enterprises. Retrieved from http://econpa.wustl.edu.8089/eps/fin/papers 0302/0302001.pdf

Berger, A., \& Udell, G. (2006). A more conceptual framework for SME financing. Journal of Banking and Finance, 30(11), 2945-2966. http://dx.doi.org/10.1016/j.jbankfin.2006.05.008

Bougheas, S., Mizen, P., \& Yalcin, C. (2005). Access to external finance: Theory and evidence on the impact of monetary policy and firm-specific characteristics. Journal of Banking \& Finance, 30(1), 199-227. http://dx.doi.org/10.1016/j.jbankfin.2005.01.002

Brealey, R. A., Myers, S. C., \& Allen, F. (2008). Principles of Corporate Finance (9th ed.). McGraw Hill Education (Asia) Co. and China Machine Press.

Burkart, M. C., \& Ellingsen, T. (2004). In-kind Finance: A Theory of Trade Credit. American Economic Review, 94(3), 569-590. http://dx.doi.org/10.1257/0002828041464579 
Cassar, G. (2004). The financing of business start-ups. Journal of Business Venturing, 19(2), 261-283. http://dx.doi.org/10.1016/S0883-9026(03)00029-6

Chandler, J. G. (2009). Marketing tactics of selected small firms in the East London CBD area. South Africa: University of South Africa.

Coco, G. (2000). On the use of collateral. Journal of Economic Surveys, 14(2), 191-214. http://dx.doi.org/10.1111/1467-6419.00109

Coleman, S., \& Cohn, R. (2000). Small firm use of financial leverage: Evidence from 1993 national survey of small business finance. Journal of Business Entrepreneurship, 12(3), 81-98.

Da Silva A. P., Hall G., \& Hutchinson P. (2007). Financial and Strategic Factors Associated with the Profitability and Growth of Small and Medium-Sized Firms in Portugal. A paper presented at International Council for Small Business, 52nd World Conference, 13th -15 th June, Turku, Finland.

Demirguc-Kunt, A., Maksimovic, V., Beck, T., \& Laeven, L. (2006). The determinant of financing obstacles. International Journal of Money and Finance, 25, 932-952. http://dx.doi.org/10.1016/j.jimonfin.2006.07.005

Dietmar, H., Stahl, K., \& Woywode, M. (1998). Legal Form, Growth and Exit of West-German firms-Empirical Results for Manufacturing, Construction, Trade, and Service Industries. Journal of Industrial Economics, 46, 453-488. http://dx.doi.org/10.1111/1467-6451.00083

Fabowale, L., Orser, B., \& Riding, A. (1995). Gender, Structural Factors, and Credit Terms between Canadian Small Businesses and Financial Institutions. Entrepreneurship Theory and Practice, 19(4), 41-65.

Fatoki, O., \& Asah, F. (2011). The Impact of Firm and Entrepreneurial Characteristics on Access to Debt Finance by SMEs in King Williams' Town, South Africa. International Journal of Business and Management, 6(8). http://dx.doi.org/10.5539/ijbm.v6n8p170

Field, A. (2005). Discovering Statistics Using SPSS (2nd ed.). London: SAGE Publications.

Frelinghaus, A., Mostert, B., \& Firer, C. (2005). Capital structure and the firm's life stage. South African Journal of Business Management, 36(4), 9-18.

Gilbert, B. A. (2008). New venture performance: does location matters? Retrieved from http://ftp.zew.de/pub/zew-docs/entrepreneurship/Gilbert.pdf

Gitman, L. J. (2007). The Principles of Managerial Finance. New York: Pearson Education Inc.

Hall, G., Hutchinson, P., \& Michealas, N. (2000). Industry effect on the determinants of Unquoted SMEs Capital Structure. International Journal of the Economic of Business, 7(3), 297-312. http://dx.doi.org/10.1080/13571510050197203

Hallberg K. (2000). A Market - Oriented Strategy for Small and Medium Scale Enterprises. International Finance Corporation Discussion Paper, 40, April. Retrieved from www.siteresources.worldbank.org/intexpcomnet/hallberg_2000.pdf

Honhyan, Y. (2009). The Determinants of Capital Structure of the SMEs: An Empirical Study of Chinese listed Manufacturing Companies. Retrieved from www.seiofbluemountain.com/search/detail.php?id=4414

Jensen, M. C., \& Meckling W. H. (1976). Theory of the firm: managerial behavior, agency cost and ownership structure. Journal of financial Economics, 3(4), 305-360. http://dx.doi.org/10.1016/0304-405X(76)90026-X

Kayanula, D., \& Quartey, P. (2000). The Policy Environment for Promoting Small and Medium -Sized Enterprises in Ghana and Malawi. Finance and Development Research Programme Working Paper Series No. 15, May. Retrieved from www.sed.manchester.ac.uk/idpm/research/publications/fdwp15.pdf

Kitindi, E. G., Magembe, B. A. S., \& Sethibe, A. (2007). Lending decision making and financial information: the usefulness of corporate annual reports to lender in Botswana. International Journal of Applied Economics and Finance, 1(2), 55-60. http://dx.doi.org/10.3923/ijaef.2007.55.66

Klapper, L., Laeven, L., \& Rajan, R. (2010). Entry regulation as a barrier to entrepreneurship. Journal of Financial Economics, 82(3), 591-623. http://dx.doi.org/10.1016/j.jfineco.2005.09.006

Kraus, A., \& Litzenberger, R. H. (1973). A state-preference model of optimal financial leverage. Journal of Finance, 9(1), 911-922. http://dx.doi.org/10.1111/j.1540-6261.1973.tb01415.x

Le, T. B. N., Venkatesh, S., \& Nguyen, V. T. (2006). Getting bank financing: study of Vietnamese private firms. Asia Pacific Journal of Management, 23(2), 209-227. http://dx.doi.org/10.1007/s10490-006-7167-8 
Majed, G. F. M., Alsharayri, A., \& Dandan, M. M. (2010). Impact of firm characteristic on Determining Financial Structure on the Insurance Sector Firms in Jordan. Journal of Social Sciences, 6(2), 282-286. http://dx.doi.org/10.3844/jssp.2010.282.286

Modigliani, F., \& Miller, M. H. (1958). The cost of capital, corporation finance and the theory of investment. American Economic Review, 48(3), 261-295.

Modigliani, F., \& Miller, M. H. (1963). Corporate income taxes and the cost of capital: A correction. American Economic Review, 53(3), 433-444.

Myers, S. C. (1984). Capital structure puzzle. Journal of Finance, 39(1), 575-592. http://dx.doi.org/10.2307/2327916

Ngoc, T. B., Le, T., \& Nguyen, T. B. (2009). The impact of networking on bank financing: The case of small and medium enterprises in Vietnam. Entrepreneurship Theory and Practice, 33(4), 867-887. http://dx.doi.org/10.1111/j.1540-6520.2009.00330.x

Olomi, D. R. (2005). Enhancing SMEs Contribution to Employment and Poverty Reduction within National Poverty Reduction Strategy. Workshop Paper on Enhancing SME's Access to Government Procurement and Food Standards by Association of Tanzanian Employers (Ate); Regency Park Hotel, Dar Es Salaam, 30th September. Retrieved from www.tanzaniagetway.org

Olutunla, G. T., \& Obamuyi, T. M. (2008). An empirical analysis of factors associated with the profitability of Small and medium - enterprises in Nigeria. African Journal of Business Management, 2(x), 195-200.

Organisation for Economic Co-operation and Development (OECD). (2004). Small and Medium - Sized Enterprises in Turkey, Issues and Policies. Retrieved from www.oecd.org/dataoecd/5/11/31932173.pdf

Pretorius, M., \& Shaw, G. (2004). Business plan in bank-decision making when financing new ventures in South Africa. South African Journal of Economics and Management Science, 7(2), 221-242.

Sanusi, J. O. (2003). Overview of Government's Efforts in the Development of SMEs and the Emergence of Small and Medium Industries Equity Investment Scheme (SMIEIS). A paper presented at the National Summit on SMIEIS organised by the Bankers' Committee and Lagos chambers of commerce and Industry (LCCI), Lagos, 10th June. Retrieved from www.cenbank.org/out/speeches/2003/govadd-10bjune.pdf

Sarapaivanich, N., \& Kotey, B. (2006). The effect of financial information quality on ability to access external finance and performance of SMEs in Thailand. Journal of Enterprising Culture, 14(3), 219-239. http://dx.doi.org/10.1142/S0218495806000143

Scott, D. F. (1972). Evidence on the importance of financial structure. Journal on Financial Management, 1(3), 45-60. http://dx.doi.org/10.2307/3665143

Shane, S. (2008). The importance of angel investing in financing the growth of entrepreneurial ventures. Retrieved from http://www.sba.gov/advo/research/rs331.pdf

Sorooshian, S., Norzima, Z., Yusuf, I., \& Rosnah, Y. (2010). Structural Modeling of Entrepreneurships effectiveness. World applied Sciences Journal, 10(8), 923-929.

Stiglitz, J., \& Weiss, A. (1981). Credit rationing in markets with imperfect information. American Economic Review, 71, 393-410.

Williams W. S (2006). Supporting the Growth of Small and Medium Enterprises. Address to the Nova Committee of the Trinidad and Tobago Chamber of Industry and Commerce; March, 16. Retrieved from www.bis.org/review/r060407d.pdf

\section{Notes}

Note 1. Programs created by the Tanzania government as part to eradicate poverty include "MKUKUTA" National Strategy for Growth and Reduction of Poverty I \& II [(NSGRP I \& II): MKUKUTA I (2005/06 2009/10): focused on accelerating economic growth, reducing poverty, improving the standard of living and social welfare of the people of Tanzania as well as good governance and accountability. MKUKUTA II, like its predecessor, is a vehicle for realizing Tanzania's Development Vision 2025, the Millennium Development Goals (MDGs)] and "MKURABITA" Property and Business Formalization Program.

Note 2. Report by: The Economic Research Bureau of the University of Dar es Salaam and the National Bureau of Statistics; July 2007. 
Note 3. Internal financing includes retained earnings, contributions from friends, family members and owner's personal savings.

Note 4. Firm characteristics are traits of the firm which has an effect in operation of the firm either positively or negatively.

Note 5. These are cost incurred when promises to creditors of a company are broken or honored with difficulty or led to bankruptcy; a common example of a cost of financial distress costs is bankruptcy costs i.e. auditors' fees, legal fees, management fees and other payments.

Note 6. Access of financing from Internal Funds (Retained Earnings) or Entrepreneurs own capital; Credit from Micro Finance Institutions (MFI); Rotating Savings and Credit associations (ROSCAs); Commercial Banks and Nonfinancial Institutions i.e. NGO.

Note 7. Include the cost of capital and risk involved in that source of finance/fund.

Note 8 . Early $17^{\text {th }}$ century; $<$ modern Latin, meaning "other things being equal"

Note 9. Accessibility of high quality production resources will enable the firm to enjoy economies of scale; and with effective marketing strategies to manage market demand in the market will lead to high productivity.

Note 10. The Framework for the Preparation and Presentation of Financial Statements as per International Accounting Standards Board

Note 11. Raosoft sample size calculator is statistical software that enables researchers to determine the sample size given the following variables: The margin of error, the confidence level, the population and the expected response distribution (Raosoft, 2010).

Note 12. Comprise agriculture and natural resources sectors including Food, Wood, Wood Products and Furniture, and Nonmetallic minerals sectors.

Note 13. This sector is made up by Manufacturing Industries include Textile; Machinery and equipments; Chemicals; Metal and Metal Products; and Other Manufacturing.

Note 14. Comprise Services and Retail business including Garments; Retail; Construction and Transport sectors.

Note 15. Sector made up by knowledge based Industries such as Electronics and Information Technology.

Note 16. Sole proprietorship and partnership form of business organization consist of lack of separate legal entity i.e. separation of business and personal affairs. 